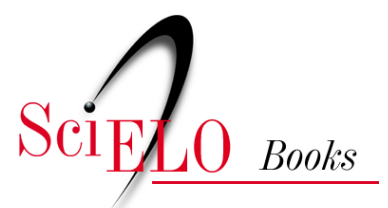

\title{
Do quê e como pesquisar
}

\author{
Sylvia Ficher
}

\section{SciELO Books / SciELO Livros / SciELO Libros}

FICHER, S. Do quê e como pesquisar. In: TREVISA, R. Cidades novas [online]. Brasília: Editora UnB, 2020, pp. 11-14. Pesquisa, inovação \& ousadia series. ISBN: 978-65-5846-158-6. https://doi.org/10.7476/9786558461586.0001.

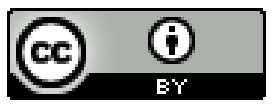

All the contents of this work, except where otherwise noted, is licensed under a $\underline{\text { Creative }}$ Commons Attribution 4.0 International license.

Todo o conteúdo deste trabalho, exceto quando houver ressalva, é publicado sob a licença Creative Commons Atribição 4.0.

Todo el contenido de esta obra, excepto donde se indique lo contrario, está bajo licencia de la licencia Creative Commons Reconocimento 4.0. 


\section{Do quê e como pesquisar}

\section{Sylvia Ficher}

Em 2004 recebi um presente do meu colega Carlos Roberto Monteiro de Andrade - para aqueles que sabem das coisas, o Mancha. Presente raro, que não se recebe todos os dias: um candidato a doutorado já pesquisador experiente e com objetos de estudo amplamente sedimentados. E assim Ricardo Trevisan entrou para a minha vida, inicialmente como orientando, para se tornar amigo dileto e, hoje, colega na Faculdade de Arquitetura e Urbanismo da Universidade de Brasília.

Sua trajetória intelectual só pode ser qualificada como afortunada. Considerando-se o seu pendor para os estudos acadêmicos, teve a sorte de entrar em 1994 para o curso de graduação em Arquitetura e Urbanismo da Escola de Engenharia de São Carlos, USP/São Carlos, curso este diferenciado justamente por sua tradição de associar ensino e investigação.

Lá passou a integrar o Archab, grupo de pesquisa liderado por Nabil Bonduki que iria produzir o mais extenso levantamento sobre habitação social no Brasil, desvelando a excepcional contribuição dos Institutos de Aposentadoria e Pensões - e que teve, entre seus principais produtos, o aclamado livro de Nabil, Origens da habitação social no Brasil (1998).

O destino estava traçado. Familiarizando-se com a prática da investigação, Ricardo tomava a habitação social como um primeiro tema de interesse. Bolsista de Iniciação Científica da Fapesp, em 1998 levou a cabo o ambicioso projeto Cidades novas de colonização e expansão territorial no noroeste do Estado de São Paulo (1930-1964), sob a orientação gabaritada de Mancha e Sarah Feldman. Foi um ano de leituras, visitas e sistematização de informações que resultou não só no 
levantamento de 42 cidades novas - valendo-se de uma fonte até hoje pouco explorada, a Enciclopédia dos municípios brasileiros -, mas também na definitiva sedução por mais dois temas, a formação da rede urbana brasileira e, nela, o papel das cidades novas. Temas suficientes para dar um sabor muito pessoal para suas reflexões.

Com o diploma de arquiteto e urbanista no bolso, em 1999 Ricardo passa seis meses em Londres para aprofundar os conhecimentos sobre a garden city. Tendo visitado alguns de seus mais significativos exemplares, como Letchworth e Welwyn, essa viagem daria o mote para o mestrado, realizado de 2001 a 2003 no Programa de Pós-Graduação em Engenharia Urbana da Universidade Federal de São Carlos, UFSCar, sob a orientação de Ricardo Siloto da Silva, mais uma vez como bolsista da Fapesp. Sua dissertação, Incorporação do ideário da garden-city inglesa na urbanística moderna brasileira: Águas de São Pedro, apresentava a estância hidromineral paulista projetada pelo engenheiro Jorge de Macedo Vieira em 1936 à nossa história urbana.

Já não haveria escapatória, diante de si impunha-se a carreira universitária. De 2003 a 2004, Ricardo leciona na Universidade Federal de Uberlândia, transferindo-se em seguida para a Universidade Estadual de Goiás. Tendo se achegado ao centro-oeste e já irrompido na minha vida, em 2006 foi aceito no doutorado da FAU/UnB, tendo o intuito de mapear o processo de projetação de cidades no território nacional. Contando com bolsa para doutorado sanduíche do CNPq, permanece de 2007 a 2008 na Europa, vinculado ao Laboratoire Architecture-Culture-Sociétés (ACS) da École Nationale Supérieure d'Architecture de Paris-Malaquais, sob a supervisão de Monique Eleb. Manteve então contatos com pesquisadores do calibre de Philippe Panerai, Jean-Louis Cohen, Donatella Calabi e Martino Tattara.

Tal intercâmbio rendeu uma guinada no desenvolvimento do doutorado, que passou a ter como objetivo melhor conceituar aquela tipologia urbana que havia tomado a imaginação de Ricardo. Em outras palavras, o desafio que ele se colocava seria responder a uma questão aparentemente banal: o que são cidades novas?

Note-se, não novas cidades em geral; afinal, toda e qualquer cidade um dia foi uma cidade nova, uma jovem cidade. Ou, já no registro do olhar obsessivo de 
pesquisador, aquelas aglomerações também denominadas: cidade nova planejada; cidade artificial; cidade protótipo; cidade de proveta; cidade construída de raiz; ville neuve; ville nouvelle; new town; cidade nova aberta; cidade nova fechada; cidade traçada; cidade planejada; cidade inventada; nova capital; nova vila; cidade concebida; cidade-sputnik; cidade ex nihilo; cidade plantada; introduced capital; cidade nascida radicalmente nova; cidade de nova fundação; cidade ideal; navyé goroda; new-town in-town; terra de Canaã; cidade concebida a priori; cidade regular; cidade surgida do nada; neue städte; twin towns; ciudad nueva; cidade de raiz; new communities; cidade concebida ex-novo; città nuova; cidade partindo do nada; cidades socialistas; cidade encomendada; cidade projetada; cidade-satélite; modoun eg gegida; città di fondazione; cidades de vontade; cidade-objeto; cidade fabricada; centro urbano novo; cidade por decreto; nuevos pueblos; cidade criada; 新しい町.

Fruto de excepcional esforço de síntese de noção tão complexa e aberta a divergências, o resultado é a tese modestamente intitulada Cidades novas. Estudo único no gênero, não só entre nós, mas no plano internacional, merece a divulgação que ora recebe, não sendo demais recomendar sua edição também em línguas estrangeiras.

Vejamos em que reside tanta excepcionalidade.

Ao buscar estabelecer uma base teórica para sua resposta, Ricardo definiu seis atributos ou genes, que deveriam estar associados em certa medida a uma aglomeração de modo a permitir classificá-la como legítimo espécime de cidade nova. Segundo ele, em um dado contexto político, econômico, social e/ou cultural podem ser consideradas como cidades novas aquelas: 1) promovidas por decisões determinadas pelo poder público ou pela iniciativa privada; 2) criadas para atender, ao menos em intenção e/ou de início, a uma ou mais demandas funcionais; 3) implantadas, portanto, em sítios presumivelmente acertados; 4) concebidas a partir de um projeto de caráter urbanístico; 5) de autoria de agentes especializados, eventualmente profissionalmente qualificados; e, por fim, 6) materializadas em tempo relativamente curto e, assim, com fundação e até mesmo data de inauguração razoavelmente estabelecida. Vontade, razão de ser, local, autores, projeto e tempo, 
seis genes inseparáveis constituindo como que o DNA da cidade nova, por sua vez articulados à longa duração da urbanização.

Mas como comprovar tal conceituação? Pelo método indutivo do registro empírico, amealhando cidades novas. Desse procedimento foi extraída a estrutura da tese: seis capítulos, cada um detalhando um gene, por sua vez ilustrado por exemplares de cidades novas de diferentes períodos e lugares, escolhidas por sua maior capacidade elucidativa. Procedimento esse que pode ser estendido ao infinito, de modo a demonstrar a abrangência da conceituação e ampliar as possibilidades de constituintes a serem nela integrados, autorizando a generalização de determinadas conclusões.

O resto é história... Defendido o doutorado em 2009, Ricardo teve seu trabalho reconhecido com o Prêmio Capes de Teses 2010. Como que parte da justa láurea, naquele ano havia entrado para o corpo docente da FAU/UnB. No mesmo pacote, ganhou o direito a um período de estudos pós-doutorados, que realizaria de 2014 a 2015 na Graduate School of Architecture, Planning and Historic Preservation da Columbia University. Sob a supervisão de Gwendolyn Wright, retornou àquele seu primeiro tema, a habitação.

Temas tão ricos ainda vão render muito. Como dele não posso mais me livrar, só me resta aguardar ansiosa a continuação das pesquisas de Ricardo Trevisan, que certamente irão contribuir para o entendimento desta que é, como bem indica a etimologia de seu nome, a fundação e o fundamento da civilização.

Brasília, 21 de março de 2018. 